\title{
Interspecific comparison of Cd bioaccumulation in European Pectinidae (Chlamys varia and Pecten maximus)
}

\author{
Marc Metiana $^{\mathrm{b}}$, Michel Warnau ${ }^{\mathrm{b}}$, François Oberhänsli ${ }^{\mathrm{b}}$, Jean-Louis Teyssiéb ${ }^{\mathrm{b}}$ and Paco \\ Bustamante $^{\text {a, * }}$
}

\begin{abstract}
${ }^{a}$ Centre de Recherche sur les Ecosystèmes Littoraux Anthropisés, UMR 6217, CNRS-IFREMER-Université de La Rochelle, 22 avenue Michel Crépeau, F-17042 La Rochelle Cedex 01, France

${ }^{\mathrm{b}}$ International Atomic Energy Agency-Marine Environment Laboratories, 4 Quai Antoine ler, MC-98000 Principality of Monaco
\end{abstract}

*: Corresponding author : P. Bustamante, email address : pbustama@univ-Ir.fr

\begin{abstract}
:
The uptake and loss kinetics of $\mathrm{Cd}$ were determined in two species of scallops from the European coasts, the variegated scallop Chlamys varia and the king scallop Pecten maximus, following exposures via seawater, phytoplankton and sediment using highly sensitive radiotracer techniques $(109 \mathrm{Cd})$. Results indicate that, for seawater and dietary pathways, C. varia displays higher bioaccumulation capacities in terms of uptake rate from water and fraction absorbed from ingested food (assimilation efficiency) than Pecten maximus. Regarding sediment exposure, P. maximus displayed low steady-state Cd transfer factor (TFSS $<1$ ); however, once incorporated, a very large part of $\mathrm{Cd}$ transferred from sediment (92\%) was strongly retained within P. maximus tissues.

Both species showed a high retention capacity for $\mathrm{Cd}$ (biological half-life, Tb1/2 > 4 months), suggesting efficient mechanisms of detoxification and storage in both species. The digestive gland was found to be the main storage organ of $\mathrm{Cd}$ in the two scallops regardless of the exposure pathway. However, Cd was stored differently within this organ according to the species considered: $40 \%$ of the total Cd was found in the soluble cellular fraction in C. varia whereas this soluble fraction reached $80 \%$ for P. maximus. This suggests that the two species displayed different $\mathrm{Cd}$ detoxification/storage mechanisms.

Finally, the present study has determined the relative contribution of the different exposure pathways to global $\mathrm{Cd}$ bioaccumulation for the two scallop species. Results clearly show that for both species, food constitutes the major accumulation pathway, contributing for $>99 \%$ and $84 \%$ of the global $\mathrm{Cd}$ bioaccumulation in C. varia and P. maximus, respectively. This work confirms the previous assumption, derived from a bibliographic overview, that dietary pathway plays a prevalent role in metal bioaccumulation in Pectinidae.
\end{abstract}

Keywords: Bivalves; Cadmium; Kinetics; Metal; Scallops; Subcellular Distribution 
50 Bivalves usually concentrate efficiently Cd from the surrounded environment (e.g. Eisler 1985). Among

51 them, Pectinidae can display very high concentrations of this non essential metal that is considered as one

52 of the most toxic ones. High levels of $\mathrm{Cd}$ in scallop tissues have been reported even for species from

53 pristine and low-contaminated areas such as the Antarctic Ocean or the sub-polar Atlantic Ocean (Mauri

54 et al. 1990, Viarengo et al. 1993, Bustamante \& Miramand 2004), suggesting that scallops have evolved a

55 natural capacity to accumulate, detoxify and store this metal in their tissues. Investigations carried out in

56 the field and in the laboratory have revealed the involvement of very efficient detoxification mechanisms.

57 Indeed, the binding of $\mathrm{Cd}$ to high-affinity cytosolic proteins, lysosomes, and mineral concretions is well

58 known to result in efficient Cd sequestration in Pectinidae (Carmichael \& Fowler 1981, Ballan-

59 Dufrançais et al. 1985, Stone et al. 1986).

60 Even though field investigations have shown that Cd levels are influenced by various factors such as

61 geographical origin, season, size and sexual maturity (Bryan 1973, Evtushenko et al. 1990, Mauri et al.

62 1990, Bustamante \& Miramand 2004, 2005a), very little is known on the dynamics of Cd

63 bioaccumulation and retention in this family. To the best of our knowledge, no study has described the Cd accumulation in Pectinidae exposed via different pathways and its depuration using environmentally realistic metal levels. For example the earlier study by Eisler et al. (1972) exposed Aquipecten irradians to $10 \mathrm{ppm} \mathrm{Cd}$, a concentration with toxic consequences (Gould et al. 1988) and therefore unlikely to produce a typical accumulation pattern for $\mathrm{Cd}$. In natural conditions, scallops are exposed to metal through seawater and food pathways, sediment potentially contributing to either or both. It is therefore necessary to investigate separately these different exposure pathways to understand their relative contribution in the global accumulation of the metal (Fowler 1982).

71 Seawater has been often considered as the main source of metal intake for marine organisms (e.g., 72 Janssen \& Scholz 1979, Borchardt 1983, Riisgard et al. 1987); however the role of the particulate phase, 


\section{MATERIALS AND METHODS}

\section{$92 \quad$ Sampling}

1996, 1999, Reinfelder et al. 1998, Wang \& Fisher 1999). In the case of Pectinidae, it has been suggested that food could be the major route of Cd intake on the basis of elevated metal concentrations found in the digestive gland (Palmer \& Rand 1977, Uthe \& Chou 1987, Bustamante \& Miramand 2005a). However, it appears necessary to confirm this assumption as the contribution of the dissolved phase could also lead to high metal concentrations in the storage and detoxification organs (e.g., Borchardt 1983).

Therefore, the present work investigated uptake and loss kinetics of $\mathrm{Cd}$ in two species of scallops, Chlamys varia and Pecten maximus exposed through seawater, food and/or sediment, depending of their different living habitats - only seawater and food for $C$. varia and all pathways for P. maximus which is living buried in the bottom sediment and is able to ingest large particles (Mikulich \& Tsikhon-Lukamina 1981, Shumway et al. 1987). The use of highly sensitive radiotracer techniques allowed studying bioaccumulation mechanisms at realistic $\mathrm{Cd}$ levels encountered in the field. Three levels of biological organization were considered in this study, the whole individual, the different organs and the subcellular fractions of the digestive gland cells, in order to evaluate the biokinetic parameters of the accumulation, the distribution among the body compartments and the cellular forms of storage in the digestive gland, respectively. Finally, we used a bioaccumulation model to determine the relative contribution of the different exposure pathways of $\mathrm{Cd}$ for both species.

In spring 2004 and 2005, one hundred variegated scallops Chlamys varia and seventy king scallops Pecten maximus were collected on the Atlantic coast (Pertuis Breton, Charente-Maritime) by SCUBA diving. They were carefully transported to IAEA-MEL premises in Monaco and were acclimatized to laboratory conditions for 4 weeks (constantly aerated open circuit aquarium; flux: $501 \mathrm{~h}^{-1}$; salinity: 36 p.s.u.; temperature: $17 \pm 0.5^{\circ} \mathrm{C} ; \mathrm{pH}: 8.0 \pm 0.1$; light/dark cycle: $12 \mathrm{~h} / 12 \mathrm{~h}$ ) prior to experimentations. 
During this period, scallops were fed daily an algal mixed diet (Isochrysis galbana, Skeletonema costatum).

\section{Radiotracer and counting}

Uptake and loss kinetics of ${ }^{109} \mathrm{Cd}$ in scallop species were determined using a high specific activity radiotracer purchased from Isotope Product $\mathrm{Lab}\left({ }^{109} \mathrm{Cd}\right.$ as $\mathrm{CdCl}_{2}$ in $\left.0.1 \mathrm{M} \mathrm{HCl}, \mathrm{T}_{1 / 2}=426.6 \mathrm{~d}\right)$. The tracer was counted using a high-resolution $\gamma$-spectrometer system composed of three Germanium -N or P typedetectors (EGNC 33-195-R, Intertechnique) connected to a multichannel analyser (Intergamma, Intertechnique). The radioactivity was determined by comparison with standards of known activity and of appropriate geometry. Measurements were corrected for counting efficiency and physical radioactive decay. The counting time was adjusted to obtain a propagated counting error less than $5 \%$.

\section{Seawater exposure}

Twenty three Chlamys varia and 23 Pecten maximus (average weight \pm SD: $30 \pm 7$ g and $208 \pm 46$ g, respectively) were placed in a 70-1 glass aquarium (constantly aerated closed circuit aquarium; salinity: 36 p.s.u.; temperature: $17 \pm 0.5^{\circ} \mathrm{C}$; $\mathrm{pH}: 8.0 \pm 0.1$; light/dark cycle: $12 \mathrm{~h} / 12 \mathrm{~h}$ ) and exposed for $7 \mathrm{~d}$ to ${ }^{109} \mathrm{Cd}$ dissolved in seawater $\left(2 \mathrm{kBq}^{-1}\right)$. No change in $\mathrm{pH}$ was detectable after the tracer addition. Spiked seawater was renewed twice a day the first two days and then daily in order to keep radioactivity in seawater constant. Activity of the ${ }^{109} \mathrm{Cd}$ in seawater was checked before and after each spike renewal, yielding time-integrated activities of $2.1 \pm 0.2 \mathrm{kBq}^{-1}$.

Nine scallops of each species were collected at different time intervals and were whole-body radioanalyzed alive (same identified individual each time). At the end of the 7-d exposure period, 5 scallops of each species were sacrificed and dissected. Shell, digestive gland, kidneys, gills, gonad, mantle, intestine, adductor muscle and the rest of soft tissues were separated and radioanalyzed in order to assess the ${ }^{109} \mathrm{Cd}$ body distribution. The remaining scallops were then placed in non contaminating 
conditions (constantly aerated open circuit; flux: $50 \mathrm{l} \mathrm{h}^{-1}$; salinity: 38 p.s.u.; temperature: $17 \pm 0.5^{\circ} \mathrm{C} ; \mathrm{pH}$ : $8.0 \pm 0.1$; light/dark cycle: $12 \mathrm{~h} / 12 \mathrm{~h}$ ) for $36 \mathrm{~d}$ and nine individuals of each species were regularly radioanalyzed alive in order to follow the loss of ${ }^{109} \mathrm{Cd}$ from the scallops. Four scallops were collected at the end of the depuration period and dissected into several body compartments as previously described.

\section{Food exposure}

The prymnesiophycean Isochrisis galbana was used to study ${ }^{109} \mathrm{Cd}$ transfer to scallops through their diet. Phytoplankton cells were exposed to $4.8 \mathrm{kBq}^{-1}{ }^{109} \mathrm{Cd}$ during their growing phase $(7 \mathrm{~d})$. After that period, phytoplankton medium was filtrated ( $1 \mu \mathrm{m}$-mesh size; Osmonic filters), and then resuspended in a 70-1 aquarium (constantly aerated closed-circuit; salinity: 36 p.s.u.; temperature: $17 \pm 0.5^{\circ} \mathrm{C}$; pH: $8.0 \pm 0.1$; light/dark cycle: $12 \mathrm{~h} / 12 \mathrm{~h}$ ) where six $C$. varia and six $P$. maximus (average weight \pm SD: $17 \pm 5 \mathrm{~g}$ and $127 \pm 14 \mathrm{~g}$, respectively) were placed for one week before the feeding experiment. The radioactivity of the labelled I. galbana was $\gamma$-counted before and after the filtration. Scallops were allowed to feed on radiolabelled I. galbana for $2 \mathrm{~h}$ (cell concentration $-510^{4}$ cell $\mathrm{ml}^{-1}$ - was selected to avoid pseudofeces production). After the feeding period, all scallops were $\gamma$-counted and flowing seawater conditions $\left(501 \mathrm{~h}^{-}\right.$ $\left.{ }^{1}\right)$ were restored in the aquarium. Individuals were then whole-body $\gamma$-counted alive at different time intervals to follow the loss kinetics of ${ }^{109} \mathrm{Cd}$. Four individuals were collected after 16 (P. maximus) and 30 $\mathrm{d}$ (C. varia) of depuration, and dissected to determine the ${ }^{109} \mathrm{Cd}$ tissue distribution among the different body compartments (shell, digestive gland, kidneys, gills, gonad, mantle, intestine, adductor muscle and the rest of soft tissues) and among the subcellular fraction of the digestive gland (see below).

\section{Sediment exposure}

Since P. maximus is living buried into the sediment whereas $C$. varia is fixed on rocks, $\mathrm{Cd}$ exposure through sediment was only assayed for P. maximus. Sediment was collected in Wimereux (North-Atlantic coast of France). Sediment grain size distribution was measured on a Mastersizer micro and the 
evaluation of the dry/wet weight ratio was calculated after freeze drying in a LABCONCO Freezone18. Aerated sediment $(9 \mathrm{~kg})$ was placed in plastic bottle, exposed to ${ }^{109} \mathrm{Cd}(516 \mathrm{kBq})$ for $6 \mathrm{~d}$ with constant agitation, then used to form a homogeneous sediment layer of $4 \mathrm{~cm}$ height in a 20-1 aquarium. Weakly bound ${ }^{109} \mathrm{Cd}$ was allowed to leach overnight under flowing seawater $\left(501 \mathrm{~h}^{-1}\right)$ (Warnau et al. 1996). Ten $P$. maximus (average weight $\pm \mathrm{SD}: 118 \pm 5 \mathrm{~g}$ ) were then placed for $13 \mathrm{~d}$ in the aquarium (constantly aerated open circuit; flux: $501 \mathrm{~h}^{-1}$; salinity: 36 p.s.u.; temperature: $17 \pm 0.5^{\circ} \mathrm{C} ; \mathrm{pH}: 8.0 \pm 0.1$; light/dark cycle: $12 \mathrm{~h} / 12 \mathrm{~h}$ ). Six individuals as well as sediment aliquots were regularly radioanalyzed during the experiment duration. ${ }^{\mathrm{A}}$ ctivity of ${ }^{109} \mathrm{Cd}$ in sediment was constant all along the exposure period $(24.2 \pm 1.9$ $\mathrm{Bq} \mathrm{g}^{-1}$ wet wt). At the end of the uptake period, 4 scallops were collected, dissected (shell, digestive gland, kidneys, gills, gonad, mantle, intestine, adductor muscle and the rest of soft tissues), weighed and $\gamma$-counted in order to determine the radiotracer distribution among the body compartments. The remaining individuals were transferred for 49 d to a new 20-1 aquarium containing non contaminated sediment with flowing seawater and they were regularly radioanalyzed to follow ${ }^{109} \mathrm{Cd}$ loss kinetics. Also, ${ }^{109} \mathrm{Cd}$ activity in sediment was regularly measured in order to ascertain that no contamination of the clean sediment occurred through ${ }^{109} \mathrm{Cd}$ recycling (for security, the whole sediment layer was renewed anyway after one week). At the end of the loss period, 4 scallops were collected and dissected as described above to determine ${ }^{109} \mathrm{Cd}$ body distribution and its subcellular distribution in the digestive gland.

\section{Subcellular distribution}

For all the experiments, the digestive gland of both scallop species were considered to assess the partitioning of ${ }^{109} \mathrm{Cd}$ between soluble and insoluble fractions as described by Bustamante \& Miramand (2005b). Briefly, part of digestive gland were homogenized individually with a mortar and pestle on ice with $10 \mathrm{ml}$ of $0.02 \mathrm{M}$ Tris-HCl buffer, $0.25 \mathrm{M}$ sucrose, $1 \mathrm{mM}$ phenylmethylsulfonylfluoride (PMSF, as protease inhibitor), at $\mathrm{pH}$ 8.6. The homogenates were centrifuged at $80,000 \mathrm{G}$ for $1 \mathrm{~h}$ at $5^{\circ} \mathrm{C}$ in a Sorvall 
RC28S ultracentrifuge to separate particle-free supernatant (cytosol; soluble fraction) from the pellet (insoluble fraction). Homogenate aliquots, cytosols, and pellets were then radioanalyzed.

\section{Data analysis}

Uptake of the radioisotope was expressed in term of concentration factors (CF: ratio between the ${ }^{109} \mathrm{Cd}$ activity in scallops $-\mathrm{Bq} \mathrm{g}^{-1}$ wet $\mathrm{wt}-$ and time-integrated activity in the seawater $-\mathrm{Bq}^{-1}$ ) over time for the seawater exposure and in term of transfer factors (TF: ratio between the ${ }^{109} \mathrm{Cd}$ activity in scallops $-\mathrm{Bq}$ $\mathrm{g}^{-1}$ wet $\mathrm{wt}-$ and time-integrated activity in the sediment $-\mathrm{Bq}^{-1}$ ) over time for the sediment exposure of P. maximus (Warnau et al. 1996, 1999). Uptake kinetics of ${ }^{109} \mathrm{Cd}$ in whole-body scallops were fitted using a simple exponential kinetic model (eq. 1) for the sediment exposure (Statistica ${ }^{\circledR}$ 6) and using a linear model for the seawater exposure (eq. 2):

$\mathrm{CF}_{\mathrm{t}}=\mathrm{CF}_{\mathrm{ss}}\left(1-\mathrm{e}^{-\mathrm{k}_{\mathrm{e}}^{\mathrm{t}}}\right)($ eq. 1$)$

$\mathrm{CF}_{\mathrm{t}}=\mathrm{k}_{\mathrm{u}} \mathrm{t}($ eq. 2$)$

where $\mathrm{CF}_{\mathrm{t}}$ and $\mathrm{CF}_{\mathrm{ss}}\left(\mathrm{CF}_{\mathrm{ss}}=\mathrm{k}_{\mathrm{u}} / \mathrm{k}_{\mathrm{e}}\right)$ are the concentration factors at time $\mathrm{t}(\mathrm{d})$ and at steady state, respectively; $k_{u}$ and $k_{e}$ are the uptake and loss rate constants $\left(d^{-1}\right)$, respectively (Whicker \& Schultz 1982 , Warnau et al. 1996).

Depuration of Cd (seawater, food and sediment experiments) was expressed in terms of percentage of remaining radioactivity (radioactivity at time $t$ divided by initial radioactivity measured in scallops at the beginning of the decontamination period *100). The percentages of remaining activity were plotted against time and loss kinetics were described by a double-component exponential model (eq. 3):

$A_{t}=A_{0 s} e^{-k_{e s}{ }^{t}}+A_{01} e^{-k_{e l} t}($ eq. 3)

where $A_{t}$ and $A_{0}$ are the remaining activities (\%) at time $t(d)$ and 0 , respectively; $k_{e}$ is the depuration rate constant $\left(\mathrm{d}^{-1}\right)$; 's' and ' $\mathrm{l}$ ' are the subscripts for the 'short-lived' and 'long-lived' components. For each exponential component ( $\mathrm{s}$ and 1 ), a biological half-life can be calculated $\left(\mathrm{T}_{\mathrm{b}^{1 / 2 \mathrm{~s}}}\right.$ and $\left.\mathrm{T}_{\mathrm{b}^{1 / 2} / 2}\right)$ from the 
corresponding depuration rate constant ( $\mathrm{k}_{\mathrm{es}}$ and $\mathrm{k}_{\mathrm{el}}$, respectively) according to the relation $\mathrm{T}_{\mathrm{b}^{1 / 2}}=\ln 2 / \mathrm{k}_{\mathrm{e}}$ (Warnau et al. 1996). Regarding feeding experiments, the 'long-lived' exponential term describes the fraction of the radiotracer ingested with food that is actually absorbed by the organism (Warnau et al. 1996). The corresponding $A_{01}$ represents the assimilation efficiency (AE) of the considered radiotracer. The best fitting regression models were selected according to highest determination coefficient and examination of residuals. The level of significance for statistical analysis was always set at $\alpha<0.05$.

\section{RESULTS}

\section{Seawater exposure}

Uptake of ${ }^{109} \mathrm{Cd}$ in whole-body $C$. varia and $P$. maximus displayed linear kinetics $\left(\mathrm{r}^{2}=0.85\right.$ and 0.66 , respectively; see Fig. 1). The values estimated for the kinetic parameters and their associated statistics are presented in Table 1. The concentration factors measured at the end of the uptake period $\left(\mathrm{CF}_{7 \mathrm{~d}}\right)$ of ${ }^{109} \mathrm{Cd}$ were $37 \pm 9$ in $C$. varia and $18 \pm 7$ in $P$. maximus (Table 2). Calculated $\mathrm{CF}_{7 \mathrm{~d}}$ for the different organs indicated that ${ }^{109} \mathrm{Cd}$ was concentrated selectively in each species, according to the following order:

- C. varia: kidneys $(928 \pm 547)>$ digestive gland $(322 \pm 175) \approx$ gills $(277 \pm 102) \approx$ foot $(265 \pm 74) \approx$ rest of soft tissues $(258 \pm 56)>$ gonad, mantle, intestine and adductor muscle $(\leq 53 \pm 11)$

- P. maximus: kidneys $(690 \pm 402) \approx$ digestive gland $(659 \pm 227)>$ gills $(175 \pm 13)>$ other tissues $(\leq 78 \pm$ 33).

In terms of body distribution, ${ }^{109} \mathrm{Cd}$ was mainly found in the digestive gland and in the gills $(\sim 30$ and 20 $\%$ of total body load, respectively) for both species. At the end of the uptake experiment, the ${ }^{109} \mathrm{Cd}$ tissue distribution shows a similar pattern $\left(\mathrm{p}_{\mathrm{G}-\text { test }}>0.40\right)$ between $C$. varia and $P$. maximus, with the digestive gland and gills accounting for more than $60 \%$ of the total Cd load (Table 2).

After the exposure period, non-contaminating conditions were restored and loss kinetics of ${ }^{109} \mathrm{Cd}$ were followed for $36 \mathrm{~d}$. The whole-body loss kinetics of ${ }^{109} \mathrm{Cd}$ in $C$. varia and $P$. maximus were best described by a two-component exponential model (Fig. 1 and Table 1). The major part of ${ }^{109} \mathrm{Cd}$ was efficiently 
absorbed in $C$. varia and $P$. maximus $\left(\mathrm{A}_{01}>77 \%\right)$. The estimated loss rate constant of the long-lived components $\left(\mathrm{k}_{\mathrm{el}}\right)$ for $C$. varia was low, i.e. $0.005 \pm 0.001$ and, consequently, the derived biological halflife reached $145 \pm 45 \mathrm{~d}$ (Table 1 ). In the case of $P$. maximus, the loss rate constant was not significantly different from $0(\mathrm{p}>0.05)$, and the related $\mathrm{T}_{\mathrm{b}^{1 / 2 l}}$ of ${ }^{109} \mathrm{Cd}$ may thus be considered as infinite.

After $36 \mathrm{~d}$ of depuration, the body distribution of ${ }^{109} \mathrm{Cd}$ displayed a similar pattern than the one observed at the end of the exposure period (Table 2). However, it is striking to note that the ${ }^{109} \mathrm{Cd}$ activity in the digestive gland of $C$. varia and $P$. maximus remained relatively constant throughout the depuration duration within the two species, i.e. from $680 \pm 369 \mathrm{~Bq} \mathrm{~g}^{-1}$ to $549 \pm 255 \mathrm{~Bq} \mathrm{~g}^{-1}$ for $C$. varia and from $1,392 \pm 479 \mathrm{~Bq} \mathrm{~g}^{-1}$ to $1,491 \pm 316 \mathrm{~Bq} \mathrm{~g}^{-1}$ for $P$. maximus, suggesting either a lack of $\mathrm{Cd}$ loss from the digestive gland during this period or a redistribution of the radioisotope from the tissues in contact with seawater towards this storage organ.

\section{Dietary exposure}

The loss kinetics of ${ }^{109} \mathrm{Cd}$ ingested with food in both $C$. varia and $P$. maximus were best fitted using a double exponential model (Fig. 1 and Table 1). C. varia displayed a higher assimilation efficiency (AE > $86 \%$ ) than $P$. maximus (AE $>80 \%$ ). However, in both species, the depuration rate constant, $\mathrm{k}_{\mathrm{el}}$, were not significantly different from $0(\mathrm{p}>0.39)$, and therefore the derived $\mathrm{T}_{\mathrm{b}^{1 / 21}}$ were infinite.

At the end of the depuration period, the digestive gland contained the main part of ${ }^{109} \mathrm{Cd}$, i.e. $97 \%$ for $C$. varia and $82 \%$ for $P$ maximus (Table 2$)$.

\section{Sediment exposure}

Sediment used in the experiment was mainly (95.8\%) composed of grains which size ranged from 76 to $302 \mu \mathrm{m}$ and its dry/wet wt ratio was 0.80 .

Whole-body uptake kinetics of sediment-bound ${ }^{109} \mathrm{Cd}$ in $P$. maximus was best fitted by a single exponential model (Table 1). TF reached steady-state equilibrium within the 2 weeks of exposure 

in the digestive gland $(3.35 \pm 1.68$; Table 3$)$. This organ also contained the main fraction of the total ${ }^{109} \mathrm{Cd}$ body burden (i.e. $78 \%$; Table 3). The body compartment containing the second highest proportion was the mantle (14\% of total ${ }^{109} \mathrm{Cd}$ body burden). The ${ }^{109} \mathrm{Cd}$ whole-body loss kinetics could not be described accurately by the exponential models; therefore a linear regression $(\mathrm{Y}=\mathrm{a} \mathrm{X}+\mathrm{b})$ was applied in order to estimate the radiotracer retention. The results showed that $92 \%$ of the accumulated ${ }^{109} \mathrm{Cd}$ were efficiently incorporated in $P$. maximus tissues, with a biological half-life not significantly different from infinite (Table 1). At the end of the depuration period ( $31 \mathrm{~d}$ ) the body distribution of ${ }^{109} \mathrm{Cd}$ was identical to that at the end of the exposure period (Table $3)$, with the highest proportion of ${ }^{109} \mathrm{Cd}$ located in the digestive gland $(\approx 80 \%)$, followed by the mantle $(\approx$ $12-14 \%$ ). In addition, the ${ }^{109} \mathrm{Cd}$ activities were similar in the two latter tissues at the end of exposure and depuration periods, viz. $81 \pm 41$ and $85 \pm 18 \mathrm{~Bq} \mathrm{~g}^{-1}$ in the digestive gland and $1.4 \pm 0.4$ and $1.5 \pm 1.4$ $\mathrm{Bq} \mathrm{g}^{-1}$ in the mantle.

\section{Subcellular distribution}

Examination of subcellular distributions indicated that, whatever the contamination pathway (i.e., seawater, food or sediment) and the sampling period (i.e., end of uptake or end of loss period), $P$. maximus stored the major part of the cellular ${ }^{109} \mathrm{Cd}$ in the soluble fraction (from 70 to $85 \%$ ). In contrast, the radiotracer was mainly bound to insoluble compounds in C. varia (Fig. 2).

\section{DISCUSSION} scallop consumption is a matter of concern. Indeed, Pectinidae are well known for their capacity of 
1973, Bustamante \& Miramand 2004, 2005b). Interestingly, this high bioaccumulation potential for Cd is not specific to anthropogenic contamination since scallops from the Antarctic Ocean have high Cd levels compare to temperate species living in the coastal waters of industrialised countries (Mauri et al. 1990, Viarengo et al. 1993).

Several field studies assumed that food would be the main intake pathway of Cd in scallops as high metal levels are always found in the digestive gland (Palmer \& Rand 1977, Uthe \& Chou 1987, Bustamante \& Miramand 2005a). However, the contribution of the dissolved phase is difficult to ascertain in the field as this route can lead to a significant uptake of $\mathrm{Cd}$ and to its redistribution towards storage tissues such as the digestive gland. Therefore, there is a need to assess the relative importance of dissolved and particulate $\mathrm{Cd}$ pathways in order to better understand their respective contributions, as well as to evaluate the retention mechanisms leading to the high Cd levels measured in scallop tissues.

The experimental exposure of Chlamys varia and Pecten maximus to ${ }^{109} \mathrm{Cd}$ via seawater confirmed their ability to concentrate $\mathrm{Cd}$ from the dissolved phase, as previously shown using elevated exposure levels of stable Cd (Eisler et al. 1972, Carmichael \& Fowler 1981). Indeed, after only 7 days of exposure to the dissolved radiotracer, both scallop species exhibited high whole-body concentration factors (CFs), with $37 \pm 9$ for $C$. varia and $18 \pm 7$ for $P$. maximus whole bodies. This difference in CF between the two species exposed to the same contamination conditions is related (1) to a higher Cd uptake rate (uptake rate constant: 5.4 vs 2.7$)$ and (2) secondarily, to a higher assimilated fraction (87.8 vs 77.1) in C. varia compared to $P$. maximus (Table 1). However in the specimens collected from the field, $C$. varia displayed typically lower Cd concentrations than P. maximus (Palmer \& Rand 1977, Uthe \& Chou 1987, Bustamante \& Miramand 2005a). This would suggest that $C$. varia has far more limited capacities of Cd storage than P. maximus.

Considering the tissues separately, the organs involved in respiration (i.e. gills), excretion (i.e. kidneys) and digestion (i.e. digestive gland) displayed higher CFs compared to other body compartments in $P$. maximus, whereas the foot and the compartment "rest of the soft tissues" also showed elevated CFs in $C$. 
varia (see Table 2). However, in terms of distribution among tissues and organs, Cd was mainly located in the digestive gland, the gills, the kidney and the mantle in both species, the digestive gland containing more than $30 \%$ of the whole body burden of ${ }^{109} \mathrm{Cd}$ (Table 2). These results strongly suggest the occurrence of efficient redistribution mechanisms towards the tissues involved in the storage, excretion and detoxification processes, i.e. the kidneys and the digestive gland (e.g., Carmichael \& Fowler 1981, Ballan-Dufrançais et al. 1985, Stone et al. 1986). It is also striking to note the difference between both species concerning the $\mathrm{Cd} C \mathrm{CF}$ in the foot that reached elevated values in $C$. varia (Table 2 ). In the latter species, the foot is well developed and contains a byssal gland which main role is to produce the byssus to stick to rocky substrates whereas $P$. maximus does not produce byssus as it lives buried in the sediment. Byssus is known to play a role in the elimination of metals from bivalves (Szefer et al. 2006), it is therefore likely that some metals are transferred from the soft tissues and concentrated in the byssus rather than merely adsorbed onto its surface from seawater. However, in the case of Cd, previous studies on mussels suggested that this metal is derived mainly from seawater (Coombs \& Keller 1981, Nicholson \& Szefer 2003). The present study was not designed to address this specific issue and our results do allow supporting internal transfer or waterborne origin of $\mathrm{Cd}$ in the byssus. However, further specificallydesigned studies using sensitive radiotracer techniques could bring most interesting information on the origin of byssal $\mathrm{Cd}$.

It is noteworthy that the $\mathrm{Cd}$ distribution pattern among the tissues was similar after $7 \mathrm{~d}$ of seawater exposure and after $36 \mathrm{~d}$ of depuration for both species (Table 2). Similarly, the subcellular distribution of Cd was identical at both times for $P$. maximus, with more than $80 \%$ in the soluble fraction of the digestive gland cells (Fig. 2). Taking into account the relatively long biological half-life of $\mathrm{Cd}$ in $P$. maximus, this result indicate that the metal is mainly bound to soluble compounds involved in the storage of this metal. The implication of metallothionein-like proteins in $\mathrm{Cd}$ detoxification and storage in the digestive gland is well documented in Pectinidae (e.g., Stone et al. 1986, Evtushenko et al. 1990, Bustamante \& Miramand 2005b). However, in C. varia, Cd was mainly bound to insoluble compounds 
(from 59 to $80 \%$; see Fig. 2), suggesting a time-limited role of the soluble metalloproteins when the metal enters through the dissolved route (as well as via the food as similar results were found for the dietary exposure; see Fig. 2). Such a predominant interaction of $\mathrm{Cd}$ with the insoluble cellular fraction in the digestive gland is not a common observation among Pectinidae but has already been shown in some species (e.g., Adamussium colbecki; Viarengo et al. 1993) and would be due to the fact that, among insoluble cellular components (i.e., organelles, membranes and granules), the lysosomal system can play a major role in Cd detoxification (by trapping) and excretion (Ballan-Dufrançais et al. 1985, Marigómez et al. 2002).

After exposure to sediment-bound Cd, P. maximus exhibited very low transfer factors (viz., $\mathrm{TF}_{\mathrm{ss}}=0.034$ \pm 0.009 ), indicating that direct contamination due to burying into sediment would represent a minor $\mathrm{Cd}$ uptake pathway in this species. However, at the end of the exposure period, $80 \%$ of the incorporated metal was found in the digestive gland, which displayed a TF higher than 3 (Table 3). As this organ is not in direct contact with the sediment, it is suggested that either (1) the radiotracer was progressively translocated from the tissues in direct contact with sediment and pore water to the digestive gland and/or (2) P. maximus was able to ingest sediment grains. Although sediment grains were never observed in the valves or in the digestive system in the many dissections carried out during this study, this latter hypothesis would be plausible as scallops were reported to be able to ingest particles of a wide size range (particles up to $950 \mu \mathrm{m}$ have been found in scallop stomachs; Mikulich \& Tsikhon-Lukamina 1981, Shumway et al. 1987). Nevertheless, the assimilated Cd in the digestive gland was efficiently retained and was mainly bound to cytosolic compounds in the same proportions as in the food experiment, supporting the hypothesis of ingestion of sediment particles.

In the case of dietary exposure, $\mathrm{Cd}$ was assimilated to a similar extent in both species, with approx. $80 \%$ of the radiotracer being incorporated in the scallop tissues. Such a high assimilation efficiency (AE) is striking as in other bivalve species, lower values were generally reported, e.g. for the tropical clam Gafrarium tumidum $(\mathrm{AE}=42 \%)$, the tropical oysters Isognomon isognomon and Malleus regula $(\mathrm{AEs}=$ 

\& Fisher 1997; Hédouin 2006). These results suggest that food would be an important source of Cd for Pectinidae. However, inter-specific differences in Cd concentrations in scallops from the field (where $C$. varia showed the lowest concentrations) are difficult to explain in regards to the results obtained in our experiments. Indeed, lower depuration rates resulted in calculated biological half-life exceeding 3 years (Table 1), meaning that virtually all the assimilated $\mathrm{Cd}$ is readily stored in $C$. varia tissues. In contrast, the biological half-life following food exposure was approx. 4 months for $P$. maximus, indicating a faster turnover of the metal compared to $C$. varia. It is therefore likely that although living in the same areas, $C$. varia and $P$. maximus do not share the same food in the marine environment. Indeed, different storage mechanisms in prey can determine Cd bioavailability to higher trophic levels (e.g., Wallace \& Lopez 1997, Wallace \& Luoma 2003). Moreover, the dissolved and sediment pathways should also have a strong importance in P. maximus (see above). The use of a bioaccumulation model is therefore a mandatory step to further explore the importance of each exposure pathways (Thomann et al. 1995, Wang \& Fisher 1999). When applying such a model, food appears to be the major route of Cd accumulation in C. varia, with $99.6 \%$ of the metal being accumulated from phytoplankton. In $P$. maximus, it was not possible to determine accurate data for the model because the kinetic parameters of the post sedimentexposure loss phase were not significant. Therefore, we only considered food and seawater pathways. In such conditions, results indicated that food accounted for $84.0 \%$ of the accumulated Cd in P. maximus. Owing to the high assimilation efficiency of sediment-bound $\mathrm{Cd}\left(\mathrm{A}_{01}=92 \%\right)$, it appears necessary to better delineate the sediment contribution to $\mathrm{Cd}$ accumulation in order to consider the three different pathways (seawater, food and sediment) on the global Cd bioaccumulation by $P$. maximus.

\section{CONCLUSION}

The present work on the bioaccumulation of $\mathrm{Cd}$ in two Pectinidae has confirmed the high $\mathrm{Cd}$ bioaccumulation potential of $C$. varia and P. maximus. The organs accumulating $\mathrm{Cd}$ to the highest extent 
in both species are the digestive gland and the kidneys whatever the exposure pathway was. Comparison of results from laboratory experiments clearly showed that $C$. varia showed higher bioconcentration and bioaccumulation capacities than $P$. maximus. Since field data have reported higher $\mathrm{Cd}$ levels in $P$. maximus than in C. varia, it is suggested that $\mathrm{Cd}$ should be bioaccumulated by other uptake pathways than food and seawater. The high assimilation efficiency of $\mathrm{Cd}$ ingested through sediment pathway in $P$. maximus indicated that the particulate pathway could play an important role in the global Cd bioaccumulation process and studies on sediment as well as on suspended particulate matter should be further investigated to better simulate the different exposure routes of $\mathrm{Cd}$ to which Pectinidae are exposed in the field. Nevertheless, differences between field and laboratory observations could be related to different detoxification mechanisms in the two species.

Acknowledgements: The IAEA is grateful for the support provided to its Marine Environment Laboratories by the Government of the Principality of Monaco. This work was supported by the IAEA, the GIP Seine-Aval, the Conseil Général de la Charente-Maritime and the CRELA (Université de la Rochelle). We thank IFREMER and the Aquarium of La Rochelle for providing the scallops. We are grateful to L. Hédouin for her help in the modelling approach. MW is an Honorary Senior Research Associate of the National Fund for Scientific Research (NFSR, Belgium).

\section{REFERENCES}

Ansell, A.D., Dao, J-C., Mason, J., 1991. Fisheries and aquaculture: three European scallops: Pecten maximus, Chlamys (Aequipecten) opercularis and Chlamys varia. In: Shumway SE (ed) Scallops: biology, ecology and aquaculture. Elsevier, p 715-752

Ballan-Dufrançais, C., Jeantet, A.Y., Feghali, C., Halpern, S., 1985. Physiological features of heavy metal storage in bivalve digestive cells and amoebocytes: EPMA and factor analysis of correspondences. Biol Cell 53:283-292 
Borchardt, T., 1983. Influence of food quantity on the kinetics of cadmium uptake and loss via food and seawater in Mytilus edulis. Mar Biol 76:67-76

Brooks, R.R., Rumsby, M.G., 1965. The biogeochemistry of trace element uptake by some New Zealand bivalves. Limnol Oceanogr 10:521-527

Bryan, G.W., 1973. The occurence and seasonal variation of trace metals in the scallops Pecten maximus (L.) and Chlamys opercularis (L.). J Mar Biol Assoc UK 53:145-166

Bustamante, P., Miramand, P., 2004. Interspecific and geographical variations of trace element concentrations in Pectinidae from European waters. Chemosphere 57:1355-1362

Bustamante, P., Miramand, P., 2005a. Evaluation of the variegated scallop Chlamys varia as a biomonitor of temporal trends of $\mathrm{Cd}, \mathrm{Cu}$, and $\mathrm{Zn}$ in the field. Environ Pollut 138:109-120

Bustamante, P., Miramand, P., 2005b. Subcellular and body distributions of 17 trace elements in the variegated scallop Chlamys varia from the French coast of the Bay of Biscay. Sci Tot Environ $337: 59-73$

Carmichael, N.G., Fowler, B.A., 1981. Cadmium accumulation and toxicity in the kidney of the bay scallop Argopecten irradians. Mar Biol 65:35-43

Coombs, T.L., Keller, P.J., 1981. Mytilus byssal threads as an environmental marker for metals. Aquatic Toxicol 1:291-300

Eisler, R., 1985. Cadmium hazards to fish, wildlife and invertebrates: a synoptic review. US Fish and Wildlife Service, Laurel, MD, 46 p

Eisler, R., Zaroogian, G.E., Hennekey, R.J., 1972. Cadmium uptake by marine organisms. J Fish Res Board Can 29:1367-1369

Evtushenko, Z.S., Lukyanova, O.N., Bel'cheva, N.N., 1990. Cadmium bioaccumulation in organs of the scallop Mizuhopecten yessoensis. Mar Biol 104:247-250

Fowler, S.W., 1982. Biological transfert and transport processes. In: G. Kullenberg (ed) Pollutant transfer and transport in the Sea. CRC Press, Inc., Boca Raton, FL, p 2-65 
Gould, E., Thompson, R.J., Buckley, L.J., Rusanowsky, D., Sennefelder, G.R., 1988. Uptake and effects of copper and cadmium in the gonad of the scallop Placopecten magellanicus: concurrent metal exposure. Mar Biol 97:217-223

Hédouin, L. 2006. Caractérisation d'espèces bioindicatrices pour la surveillance des activités minières et la gestion de l'environnement en milieu récifal et lagonaire : application au lagon de la NouvelleCalédonie. PhD thesis, University of La Rochelle, France, 327 p

Janssen, H.H., Scholz, N., 1979. Uptake and cellular distribution of cadmium in Mytilus edulis. Mar Biol $55: 133-141$

Marigómez, I., Soto, M., Cajaraville, M.P., Angulo, E., Giamberini, L., 2002. Cellular and subcellular distribution of metals in molluscs. Microsc Res Techniq 56:358-392

Mauri, M., Orlando, E., Nigro, M., Regoli, F., 1990. Heavy metals in the Antarctic scallop Adamussium colbecki. Mar Ecol Prog Ser 67:27-33

Mikulich, L.V., Tsikhon-Lukamina, A., 1981. Food of the scallop. Oceanology 21:633-635

Nicholson, S., Szefer, P., 2003. Accumulation of metals in the soft tissues, byssus and shell of the mytilid mussel Perna viridis (Bivalvia: Mytilidae) from polluted and uncontaminated locations in Hong Kong coastal waters. Mar Pollut Bull 46:1040-1043

Palmer, J., Rand, G., 1977. Trace metal concentrations in two shellfish species of commercial importance. Bull Environ Contam Toxicol 18:512-520

Reinfelder, J.R., Fisher, N.S., Luoma, S.N., Nichols, J.W., Wang, W-X., 1998. Trace element trophic transfer in aquatic organisms: A critique of the kinetic model approach. Sci Tot Environ 219:117135

Riisgard, H.U., Bjornestad, E., Mohlenberg, F., 1987. Accumulation of cadmium in the mussel Mytilus edulis: kinetics and importance of uptake via food and seawater. Mar Biol 96:349-353

Shumway, S.E., Selvin, R., Schick, D.F., 1987. Food resources related to habitat in the scallop Placopecten magellanicus (Gmelin, 1791): A qualitative study. J Shellfish Res 6:89-95 
Stone, H.C., Wilson, S.B., Overnell J., 1986. Cadmium binding components of scallop (Pecten maximus) digestive gland. Partial purification and characterization. Comp Biochem Physiol C 85:259-268

Szefer, P., Fowler, S.W., Ikuta, K., Paez Osuna, F., Ali, A.A., Kim, B-S., Fernandes, H.M., Belzunce, MJ., Guterstam, B., Kunzendorf, H., Wołowicz, M., Hummell, H., Deslous-Paoli, M. 2006. A comparative assessment of heavy metal accumulation in soft parts and byssus of mussels from subarctic, temperate, subtropical and tropical marine environments. Environ Pollut 139:70-78

Thomann, R.V., Mahony, J.D., Mueller, R., 1995. Steady-state model of biota sediment accumulation factor for metals in two marine bivalves. Environ Toxicol Chem 14:1989-1998

Uthe, J.F., Chou, C.L., 1987. Cadmium in sea scallop (Plactopecten magellanicus) tissues from clean and contaminated areas. Can J Fish Aquat Sci 44:91-98

Viarengo, A., Canesi, L., Massu-Cotelli, A., Ponzano, E., Orunesu, M., 1993. Cu, Zn, Cd content in different tissues of the Antarctic scallop Adamussium colbecki (Smith 1902): role of metallothionein in the homeostasis and in the detoxification of heavy metals. Mar Environ Res $35: 216-217$

Wallace, W.G., Lopez, G.R., 1997. Bioavailability of biologically sequestered cadmium and the implications of metal detoxification. Mar Ecol Prog Ser 147:149-157

Wallace, W.G., Luoma, S.N., 2003. Subcellular compartmentalization of Cd and Zn in two bivalves. II. Significance of trophically available metal (TAM). Mar Ecol Prog Ser 257:125-137

Waller, T.R., 1991. Evolutionary relationships among commercial scallops (Mollusca: Bivalvia: Pectinidae). In: Shumway SE (ed) Scallops: biology, ecology and aquaculture. Elsevier, p 1-74

Wang, W-X., Fisher, N.S., 1997. Modeling metal bioavailability for marine mussels. Rev Environ Contam Toxicol 151:39-65

Wang, W-X., Fisher, N.S., 1999. Delineating metal accumulation pathways for marine invertebrates. Sci Tot Environ 237/238:459-472 
472 Warnau, M., Teyssié, J.L., Fowler, S.W. 1996. Biokinetics of selected heavy metals and radionuclides in the common Mediterranean echinoid Paracentrotus lividus: sea water and food exposures. Mar. Ecol Prog Ser 141: 83-94

475 Whicker, F.W., Schultz, V., 1982. Radioecology: nuclear energy and the environment, Vol. 2. CRC Press, Boca Raton, FL, 320 p 
Table 1. Chlamys varia and Pecten maximus. Whole-body uptake and loss kinetic parameters of ${ }^{109} \mathrm{Cd}$ following different exposure experiments:

478 1) 7-d exposure via seawater $(n=9)$ followed by $36 \mathrm{~d}$ of depuration $(\mathrm{n}=9)$;

479 2) 2-hr feeding on radiolabelled Isochrysis galbana followed by a depuration period of $16 \mathrm{~d}(P$. maximus, $\mathrm{n}=6)$ or $30 \mathrm{~d}(C$. varia, $\mathrm{n}=6)$;

480 3) 13-d exposure of $P$. maximus via the sediments $(\mathrm{n}=8)$ followed by $31 \mathrm{~d}$ of depuration $(\mathrm{n}=8)$.

481 Uptake parameters: $\mathrm{CF}_{\mathrm{ss}} / \mathrm{TF}_{\mathrm{ss}}$ concentration and transfer factors at steady state; $\mathrm{k}_{\mathrm{u}}$ : uptake rate constant $\left(\mathrm{d}^{-1}\right)$

482 Depuration parameters: $\mathrm{A}_{0 \mathrm{~s}}$ and $\mathrm{A}_{01}$ : activity (\%) lost according to the short- and the long-lived exponential component, respectively; $\mathrm{T}_{\mathrm{b}^{1 / 2}}$ : 483 biological half-life (d). ASE: asymptotic standard error; $\mathrm{r}^{2}$ : determination coefficient of the uptake or loss kinetics

\begin{tabular}{|c|c|c|c|c|c|c|c|c|c|}
\hline \multirow[b]{2}{*}{ Experiment } & \multirow[b]{2}{*}{ Species } & \multicolumn{3}{|c|}{ a. Uptake } & \multicolumn{5}{|c|}{ b. Loss } \\
\hline & & $\mathrm{CF}_{\mathrm{ss}} / \mathrm{TF}_{\mathrm{ss}} \pm \mathrm{ASE}$ & $\mathrm{k}_{\mathrm{u}} \pm \mathrm{ASE}$ & $\mathrm{r}^{2}$ & $\mathrm{~A}_{0 \mathrm{~s}} \pm \mathrm{ASE}$ & $\mathrm{T}_{\mathrm{b}^{1} / 2 \mathrm{~s}} \pm \mathrm{ASE}$ & $\mathrm{A}_{01} \pm \mathrm{ASE}$ & $\mathrm{T}_{\mathrm{b}^{1 / 2} / 2} \pm \mathrm{ASE}$ & $r^{2}$ \\
\hline \multirow[t]{2}{*}{ 1) Seawater } & C. varia & - & $5.4 \pm 0.2^{\mathrm{d}}$ & 0.85 & $12.2 \pm 3.8^{b}$ & 0.8 & $87.8 \pm 2.4^{\mathrm{d}}$ & $145 \pm 45^{b}$ & 0.31 \\
\hline & P. maximus & - & $2.7 \pm 0.1^{\mathrm{d}}$ & 0.66 & $23.4 \pm 5.7^{\mathrm{c}}$ & 1.1 & $77.1 \pm 4.8^{\mathrm{d}}$ & 913 & 0.49 \\
\hline \multirow[t]{2}{*}{ 2) Feeding } & C. varia & - & - & - & $14.5 \pm 4.1^{\mathrm{c}}$ & 0.4 & $85.8 \pm 2.1$ & 989 & 0.21 \\
\hline & P. maximus & - & - & - & $20.5 \pm 6.1^{b}$ & 0.02 & $79.5 \pm 3.7^{d}$ & 138 & 0.37 \\
\hline 3) Sediment & P. maximus & $0.034 \pm 0.002^{\mathrm{d}}$ & $0.014 \pm 0.002^{\mathrm{d}}$ & 0.62 & $\mathrm{NC}$ & $\mathrm{NC}$ & $92^{\mathrm{d}}$ & $\mathrm{NC}$ & - \\
\hline
\end{tabular}

484

Probability of the model adjustment: ${ }^{\mathrm{a}} \mathrm{p}<0.05,{ }^{\mathrm{b}} \mathrm{p}<0.01,{ }^{\mathrm{c}} \mathrm{p}<0.001,{ }^{\mathrm{d}} \mathrm{p}<0.0001$; NC: not calculated 
487 Table 2. Chlamys varia and Pecten maximus. Concentration Factors (mean CF \pm SD) and 488 tissue distribution (mean $\% \pm \mathrm{SD}$ ) of ${ }^{109} \mathrm{Cd}$ during seawater (end of exposure and depuration 489 periods) and feeding experiments (16 and $30 \mathrm{~d}$ after feeding for P. maximus and C. varia, 490 respectively).

\begin{tabular}{|c|c|c|c|c|}
\hline \multirow{3}{*}{$\begin{array}{l}\text { Species } \\
\text { Compartments }\end{array}$} & \multicolumn{3}{|c|}{ Seawater contamination } & \multirow{3}{*}{$\begin{array}{c}\text { Food contamination } \\
\text { Loss }(\mathrm{n}=5) \\
\text { Distribution } \\
(\%)\end{array}$} \\
\hline & \multicolumn{2}{|c|}{ Uptake (7 d, n=5) } & \multirow{2}{*}{$\begin{array}{c}\text { Loss }(36 \mathrm{~d}, \mathrm{n}=4) \\
\text { Distribution } \\
(\%)\end{array}$} & \\
\hline & $\begin{array}{l}\text { Concentration } \\
\text { Factor }\end{array}$ & $\begin{array}{c}\text { Distribution } \\
(\%)\end{array}$ & & \\
\hline \multicolumn{5}{|l|}{ Chlamys varia } \\
\hline Digestive gland & $322 \pm 175$ & $33 \pm 14$ & $41 \pm 18$ & $97 \pm 1$ \\
\hline Gills & $277 \pm 102$ & $30 \pm 9$ & $23 \pm 6$ & $<1$ \\
\hline Kidneys & $928 \pm 547$ & $13 \pm 6$ & $15 \pm 8$ & $<1$ \\
\hline Intestine & $23 \pm 7$ & $<1$ & $1 \pm 1$ & $<1$ \\
\hline Gonad & $45 \pm 65$ & $1 \pm 1$ & $1 \pm 1$ & $1 \pm 0$ \\
\hline Foot & $265 \pm 74$ & $3 \pm 1$ & $2 \pm 0$ & $<1$ \\
\hline Mantle & $53 \pm 11$ & $12 \pm 4$ & $10 \pm 6$ & $<1$ \\
\hline Adductor muscle & $21 \pm 6$ & $4 \pm 1$ & $5 \pm 3$ & $<1$ \\
\hline Remaining tissues & $258 \pm 56$ & $5 \pm 1$ & $2 \pm 0$ & $0 \pm 1$ \\
\hline Whole body & $37 \pm 9$ & & & \\
\hline \multicolumn{5}{|l|}{ Pecten maximus } \\
\hline Digestive gland & $659 \pm 227$ & $38 \pm 10$ & $49 \pm 5$ & $82 \pm 19$ \\
\hline Gills & $175 \pm 13$ & $28 \pm 11$ & $19 \pm 2$ & $1 \pm 0$ \\
\hline Kidneys & $690 \pm 402$ & $10 \pm 4$ & $12 \pm 4$ & $6 \pm 12$ \\
\hline Intestine & $16 \pm 3$ & $<1$ & $<1$ & $1 \pm 1$ \\
\hline Gonad & $18 \pm 10$ & $2 \pm 2$ & $2 \pm 1$ & $9 \pm 17$ \\
\hline Foot & $13 \pm 5$ & $<1$ & $<1$ & $1 \pm 1$ \\
\hline Mantle & $28 \pm 5$ & $11 \pm 2$ & $10 \pm 7$ & $<1$ \\
\hline Adductor muscle & $18 \pm 7$ & $9 \pm 3$ & $7 \pm 1$ & $<1$ \\
\hline Remaining tissues & $78 \pm 33$ & $2 \pm 0$ & $1 \pm 0$ & $1 \pm 0$ \\
\hline Whole body & $18 \pm 7$ & & & \\
\hline
\end{tabular}

491

492

493

494 
495 Table 3. Pecten maximus. Transfer Factors (mean TF $\pm \mathrm{SD} ; \mathrm{n}=4$ ) of ${ }^{109} \mathrm{Cd}$ after a 13-d 496 exposure via sediment and tissue distribution (mean $\% \pm \mathrm{SD}$ ) of ${ }^{109} \mathrm{Cd}$ at the end of the $13-\mathrm{d}$ 497 exposure and 31-d depuration period $(n=5)$.

\begin{tabular}{|c|c|c|c|c|}
\hline \multirow[t]{3}{*}{ Compartments } & \multicolumn{2}{|c|}{ Uptake phase } & \multirow{2}{*}{\multicolumn{2}{|c|}{$\begin{array}{l}\text { Loss phase } \\
\text { Distribution }^{499}\end{array}$}} \\
\hline & Transfer & Distribution & & \\
\hline & Factor & $(\%)$ & $(\%)$ & 500 \\
\hline Digestive gland & $3.35 \pm 1.68$ & $78 \pm 10$ & $80 \pm 10$ & 501 \\
\hline Gills & $0.05 \pm 0.04$ & $4 \pm 3$ & $6 \pm 1$ & 500 \\
\hline Kidneys & $0.12 \pm 0.04$ & $1 \pm 1$ & $<1$ & 502 \\
\hline Intestine & $0.09 \pm 0.05$ & $<1$ & $<1$ & 503 \\
\hline Gonad & $0.06 \pm 0.05$ & $1 \pm 0$ & $<1$ & 504 \\
\hline Foot & $0.03 \pm 0.01$ & $<1$ & $<1$ & 505 \\
\hline Mantle & $0.06 \pm 0.02$ & $14 \pm 8$ & $12 \pm 10$ & 505 \\
\hline Adductor muscle & $0.00 \pm 0.00$ & $1 \pm 1$ & $<1$ & 506 \\
\hline Remaining tissues & $0.06 \pm 0.05$ & $1 \pm 1$ & $<1$ & \\
\hline Whole body & $0.04 \pm 0.01$ & & & \\
\hline
\end{tabular}


514 Isochrysis galbana (loss kinetics B; Remaining activity -\%-; mean $\pm \mathrm{SD} ; \mathrm{n}=6$ C. varia and $\mathrm{n}$ $515=9$ P. maximus $)$.

Caption to figures.

Figure 1. Chlamys varia and Pecten maximus. Uptake and loss kinetics of ${ }^{109} \mathrm{Cd}$ in scallops exposed for $7 \mathrm{~d}$ via seawater (uptake kinetics A1; Concentration Factors -CF-; mean \pm SD; $n$ $=9$ ), then maintained for $36 \mathrm{~d}$ in non contaminated conditions (loss kinetics A2; Remaining activity $-\%-;$ mean $\pm \mathrm{SD} ; \mathrm{n}=9$ ) and after a 2 -hr feeding on radiolabelled phytoplankton

Figure 2. Chlamys varia and Pecten maximus. Subcellular distribution of ${ }^{109} \mathrm{Cd}$ in the digestive gland cells following different exposure experiments: (1) 7-d exposure via seawater followed by $36 \mathrm{~d}$ of depuration; (2) 2-hr feeding on radiolabelled Isochrysis galbana followed by a depuration period of $16 \mathrm{~d}$ ( $P$. maximus) or $30 \mathrm{~d}$ (C. varia); (3) 13-d exposure of $P$. maximus via the sediments followed by $31 \mathrm{~d}$ of depuration. 
A1. Uptake via seawater

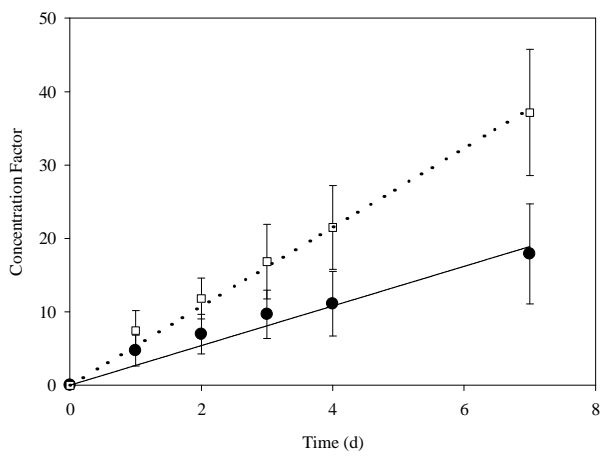

A2. Loss after seawater exposure

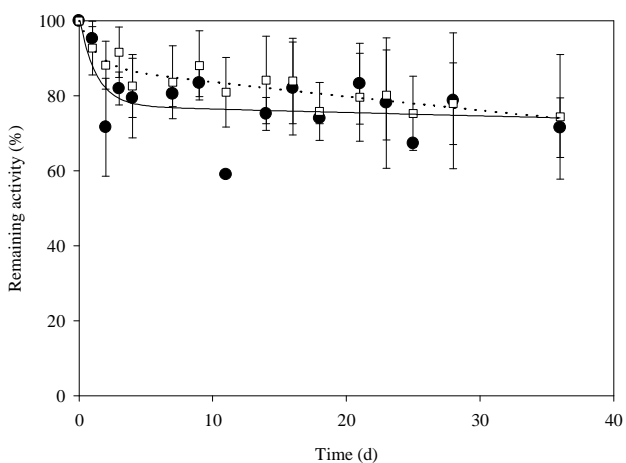

B. Loss after food exposure

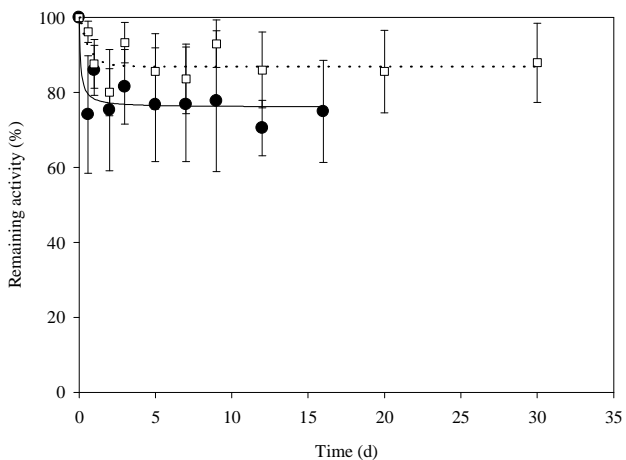

…........... Chlamys varia $\longrightarrow$ Pecten maximus

Figure 1.

4 


\section{Pecten maximus}

Uptake (7 d, $\frac{\text { Seawater }}{\mathrm{n}=5) \quad \text { Loss }(36 \mathrm{~d}, \mathrm{n}=5)}$
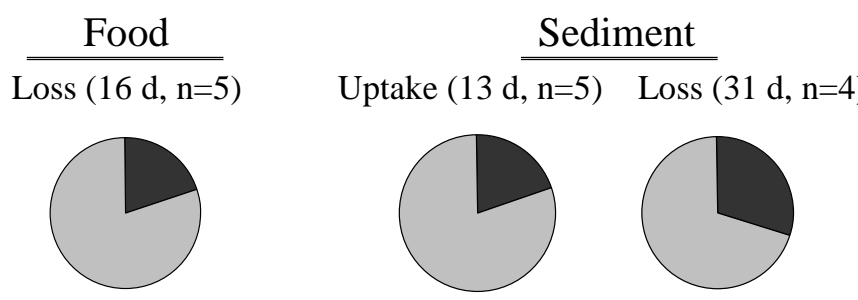

Chlamys varia

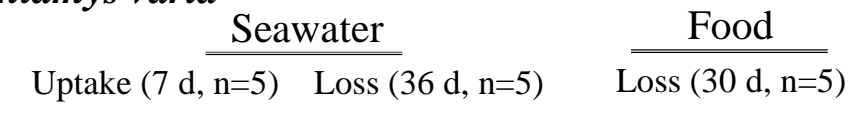

6
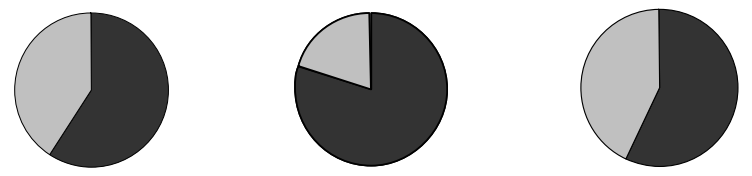

$\square$ Soluble fraction

Insoluble fraction

Figure 2. 